\title{
A longitudinal literature review of life cycle costing applied to urban agriculture
}

\author{
Alexandra Peña ${ }^{1}\left[\right.$ : M. Rosa Rovira-Val ${ }^{1,2}$ \\ Received: 25 September 2019 / Accepted: 13 May 2020 / Published online: 2 June 2020 \\ (C) The Author(s) 2020
}

\begin{abstract}
Purpose The aim of this research is to carry out a literature review of the use of life cycle costing (LCC) in the urban agriculture (UA) sector by analysing its evolution over a 22-year period from its beginning in 1996 to July 2018.

Methods A total of 442 references were obtained from two principal databases, Scopus and Web of Science (WoS). After a long refining process, 20 (4.5\%) references containing the keywords LCC and UA were selected for analysis. Then, we classified and organized the selected references in 4 groups. Qualitative methods were used for analysis, and results on general characteristics of the 20 references and by each group were elaborated. Lastly, we discussed and concluded the most significant findings. Limitations and future research were also included.

Results and discussion Our major findings were as follows: (i) urban horticulture was the most studied urban agriculture practice among studies that used LCC for UA; (ii) LCC plays a secondary role in its integration with LCA; (iii) only 4 of the10 papers in group 1 used additional financial tools; (iv) very few (3) papers appropriately applied the four main LCC stages; and on the other side, essential costs like infrastructure, labour, maintenance, and end-of-life were frequently not included.

Conclusions Since we found that life cycle assessment (LCA) was the predominant methodology, we suggest that future research apply both LCA and LCC analyses at the same level. The LCC analysis was quite incomplete in terms of the costs included in each LCC stage. We recommend that the costs at the initial or construction stage be considered a necessity in future studies in order to implement these new systems on a large scale. Due to the limited use of labour cost at the operation stage, we also suggest that labour be included as an essential part of the urban production process. Finally, for more complete LCC analysis for UA, we recommend (i) that all LCC stages be considered and (ii) that additional financial tools, such as net present value (NPV), internal rate of return (IRR) and payback period (PBP), be used to complement the LCC analysis.
\end{abstract}

Keywords LCC $\cdot$ Life cycle cost $\cdot$ Life cycle costing $\cdot$ Life cycle costanalysis $\cdot$ Lifecycle sustainability assessment $($ LCSA $) \cdot$ Urban agriculture $\cdot$ Literature review $\cdot$ Economic sustainability

\section{Introduction}

Responsible editor: Greg Thoma

Alexandra Peña

alexandra.pena@uab.cat

1 Sostenipra (SRG 01412), Institute of Environmental Science and Technology (ICTA-UAB), Z Building, Universitat Autònoma de Barcelona (UAB), Campus Bellaterra, Cerdanyola del Vallès, 08193 Barcelona, Spain

2 Business Department, B Building, Universitat Autònoma de Barcelona (UAB), Campus Bellaterra, Cerdanyola del Vallès, 08193 Barcelona, Spain

Nowadays, more than half of the world's population lives in urban areas, and this tendency is expected to increase to $68 \%$ by 2050 (UN DESA 2018). For example, in the European Union alone, $75 \%$ of the population lives in cities, and this number is estimated to reach $80 \%$ by 2020 .

As a result, rapid urbanization can bring an extensive range of undesirable consequences, such as a reduction in fertile lands, deforestation, water and air pollution, reduced drainage of rainfall, poverty and problems in the supply of fresh food (Baud 2000). In this sense, some experts are concerned about the capacity of the biosphere to provide enough food for the increased human population in urban areas (Gilland 2006). 
To find a solution to cities' fresh food problems, Nadal et al. (2015) suggested that new forms of agriculture should be found to guarantee food security for the population at a lower cost within the framework of sustainable development. Urban agriculture (UA) would be a good example of this.

In the literature, there are many definitions of UA, but in general, it can be defined as "an industry located within (intraurban) or on the fringe (peri-urban) of a town, city or metropolis, which grows or raises, processes and distributes a diversity of food and non-food products..." (Mougeot, 2000, p.11). UA is a broad term and includes not only plant cultivation and animal rearing but also other related activities such as the production and selling of agricultural inputs, post-harvesting, marketing and commercialization.

According to many authors, UA, which provides fresh food in urban settlements, may alleviate cities' food problems and simultaneously contribute to their sustainability (SanyéMengual et al. 2017; Specht et al. 2014; Benis and Ferrão 2018; Ackerman et al. 2014; Goldstein et al. 2016; Opitz et al. 2016). In this regard, various authors found a strong relationship between UA and the three pillars of sustainability: environment, economy and society.

To assess the different levels of sustainability of UA, the use of an appropriate methodology is needed. Pieces of evidence from the scientific literature show that life cycle sustainability assessment (LCSA) is the main methodology used for this purpose in many studies (Sanyé-Mengual et al. 2015a; Liaros et al. 2016; Sanyé-Mengual et al. 2018; Kim and Zhang, 2018; Dorr et al. 2017; Benis et al. 2018). Three distinct analyses are available in the framework of LCSA: life cycle assessment (E-LCA or LCA), which is used for the evaluation of environmental aspects; life cycle costing (LCC), which is used for the evaluation of economic aspects and social life cycle assessment (S-LCA), which is used for the evaluation of the social aspects of sustainability (Kloepffer 2008; Swarr et al. 2011).

As far as we know, most UA studies focus mainly on the environmental aspects of UA by using LCA. In this sense, LCA is the most widely used life cycle methodology based on its implementation and the interpretation of its results (Orsini et al. 2014; Goldstein et al. 2016; Sanjuan-Delmás et al. 2018). While the environmental aspects of UA are extensively studied in the literature, an evaluation of the economic aspects of UA through LCC is still missing (SanyéMengual et al. 2017). Some authors have used combined LCA and LCC analyses, but the results are not relevant because LCA and LCC can be correlated negatively and positively; i.e. financial feasibility does not always mean environmental viability and vice versa (European Commission 2010).

The aim of LCC is to quantify the total cost over the life cycle of a project to identify the cost-effectiveness of alternative projects for input into a decision-making or evaluation process (Norris 2001; ISO 2008). LCC, also known as life cycle cost analysis (LCCA), is an economic evaluation technique that takes into consideration all costs and cash flows that appear during the life cycle of a project, product or service (Ammar et al.2013) from the costs of design and acquisition through to operation, maintenance and disposal (Wu and Longhurst 2011; ISO 2008).

There are other popular methods for assessing the economic performance of a project or product, such as the cost-benefit analysis (CBA) (Carter and Keeler 2008; Sanyé-Mengual et al. 2015a; Benis et al. 2018) and whole life costing (WLC) (ISO 2008). The characteristics and procedures of CBA and WLC however are very similar to those of LCC and most of the time that authors refer to their methods as CBA or WLC while the methodology that they have used is LCC.

This methodology became popular in the mid-1960s, but 1996 is considered the starting point because in this year, the first official document describing the theoretical framework for LCC, the handbook entitled Life Cycle Costing Manual for the US Federal Management Program (Fuller and Petersen, 1996), was published. Currently, LCC is spread worldwide and is one of the most commonly used procedures for economic assessment in different industries. Evidence from the scientific literature shows the growing interest in this methodology in industry, infrastructure, construction and building sectors (Naves et al. 2018).

As far as we know, there is no evidence of a literature review on LCC applied to UA because the only LCC review papers that we found were for the aforementioned sectors. The purpose of this paper is fill this gap by studying the evolution of LCC analysis in a UA context from 1996 to July 2018 by conducting a literature review.

This study is the first attempt to systematize the existing academic literature on the use of LCC for the growing UA sector. The results will be helpful in identifiying common problems in LCC calculation, analysis and interpretation. The findings will also serve as a guide for future researchers by promoting a greater application of LCC in the UA sector.

We have organized the paper as follows:

Part 1: Introduction,

Part 2: Methods,

Part 3: Results,

Part 4: Discussion, and

Part 5: Conclusions.

\section{Methods}

This study is a longitudinal analysis of a 22-year period, from 1996 to July 2018. The year 1996 is the starting point of our investigation because it is the year of the publication of the first official paper containing a theoretical framework for LCC (Fuller and Petersen, 1996). 
Fig. 1 Research methodology process

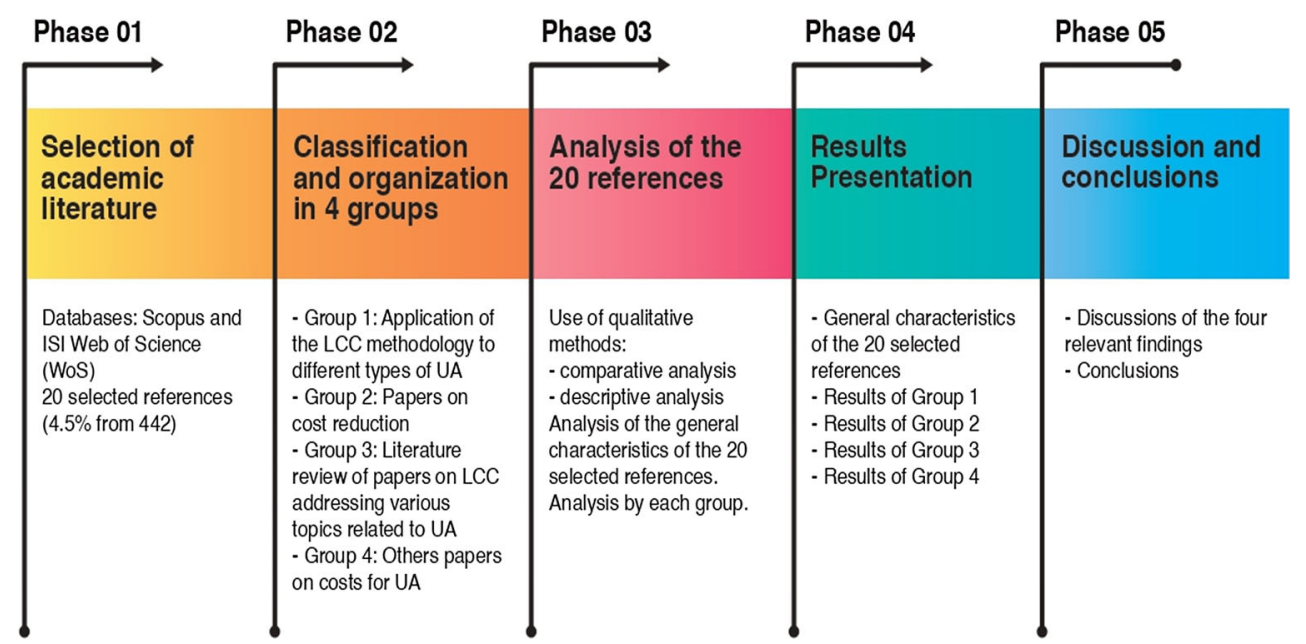

Figure 1 shows the methodology used for this research including five phases which we explain below.

The first phase was to select the academic papers for our review. Therefore, we had to find the most appropriate keywords to successfully describe the relationship between LCC and UA. For LCC, we chose the 4 most popular words: LCC, life cycle cost, life cycle costing and life cycle cost analysis. As for UA, we found a greater number of different terms, but the most popular were urban agriculture (Orsini et al. 2013; Goldstein et al. 2016; SanyéMengual et al. 2017; Hamilton et al. 2014; Specht et al. 2014); urban gardening/gardens (Orsini et al. 2013; Grewal and Grewal 2012); urban farming/farms (Orsini et al. 2013; Specht et al. 2014) and rooftop greenhouse/

Table 1 Database of different words and terms regarding UA

Urban agriculture (UA)

Vertical agriculture

Urban rooftop agriculture (URA)

Others
Urban farming/farms

Urban gardening/gardens Urban food systems

Vertical farming/vertical farms Vertical farm systems

Zero-acreage farming (zfarming)

Vertical greenhouses

Indoor farms

Interior gardens

Urban horticultural systems

Organoponics

Soilless systems

Hydroponics

Building-integrated agriculture

Rooftop greenhouses

Rooftop gardens

Rooftop farming/farms

Hydroponic rooftop gardening/gardens

Community gardens

Home gardens

Agricultural gardens

Allotments of urban land

Urban park garden/farms (Cerón-Palma et al. 2012; Orsini et al.2014; Sanyé-Mengual et al. 2015b; Sanyé-Mengual et al. 2015c; Dorr et al. 2017; Sanyé-Mengual et al. 2017; Zinia and McShane 2018; Artmann and Sartison, 2018). To organize our database, we classified all the different words and terms regarding UA into five groups (see Table 1). After that, we created different combinations of the keywords for both LCC and UA.

Scopus and ISI Web of Science (WoS) online databases were selected because they are the most widespread and are used by several authors in the field (Petit-Boix et al.2017; Ilg et al. 2017; Kambanou and Lindahl 2016; Scope et al. 2016). As a result, we obtained 442 references, 223 were from WoS and 219 from Scopus, which then had to be refined. Given that the abbreviation LCC can be linked to other expressions and concepts, we had to remove the results which were not associated with LCC. Moreover, the focus of our research was on UA only; therefore, we also excluded papers on conventional agriculture from the analysis. Consequently, the remaining references included both LCC and UA. Finally, we removed all the repeated references. The final result was 20 references for analysis ( $4.5 \%$ of the initial 442) containing both terms LCC and UA.

Then, the second phase was to classify the selected references into 4 groups. The underlying criteria for classification were similarity of the topic and type of the study (empirical or literature review).

Group 1: Application of the LCC methodology to different types of UA consisted of 10 papers describing the use of LCC methodology in different types of UA, e.g. home gardens, rooftop greenhouses and aquaponics systems. In Group 2: Papers on cost reduction were made up of 3 papers on cost reduction. Group 3: Literature review of papers on life cycle costs addressing various topics related to UA included 4 literature reviews. Group 4: Other papers on costs for UA were composed of 3 research papers on costs of UA which did not specify the methodology used. 
Fig. 2 Number of publications by year

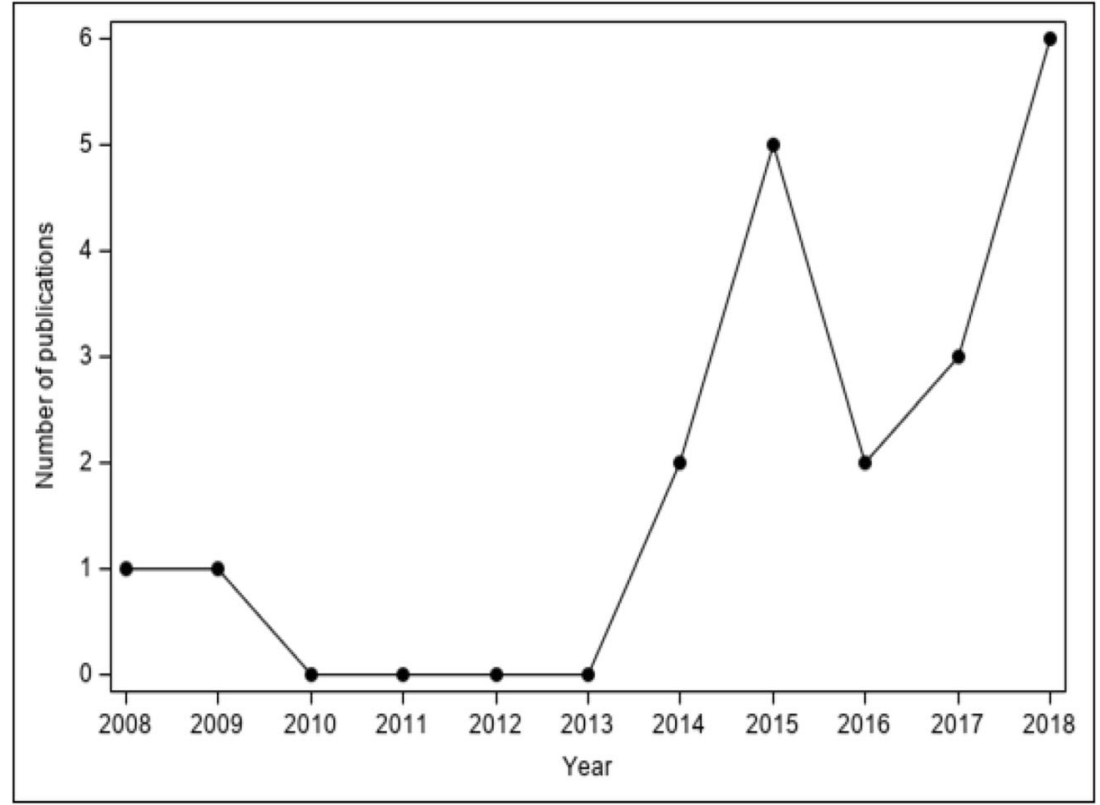

The third phase was to analyse both the characteristics of the set of 20 selected references as a whole and the distinctive aforementioned groups using qualitative methods (Saldaña 2003; Ragazzi 2017). We mainly used comparative analysis, but in some cases, a descriptive analysis was applied when it was not possible to compare. The next stage (phase 4) was to present the results on general characteristics of the 20 selected references and the results group by group.

The last step of the methodological process (phase 5) was to discuss and conclude the most relevant findings. Limitations and suggestions for future research were also presented.

\section{Results}

In this section, we present the results on the general characteristics of the 20 references in terms of the number of publications by year, type of paper and source, leading regions and countries to show the evolution of the use of LCC for UA. After that, the results by groups are presented.

\subsection{General characteristics}

In this section, we present the general characteristics of the 20 papers selected.

We found that the first scientific paper on LCC applied to UA was published in 2008 (Nguyen and Weiss 2008) just
Fig. 3 Type of source and type of paper

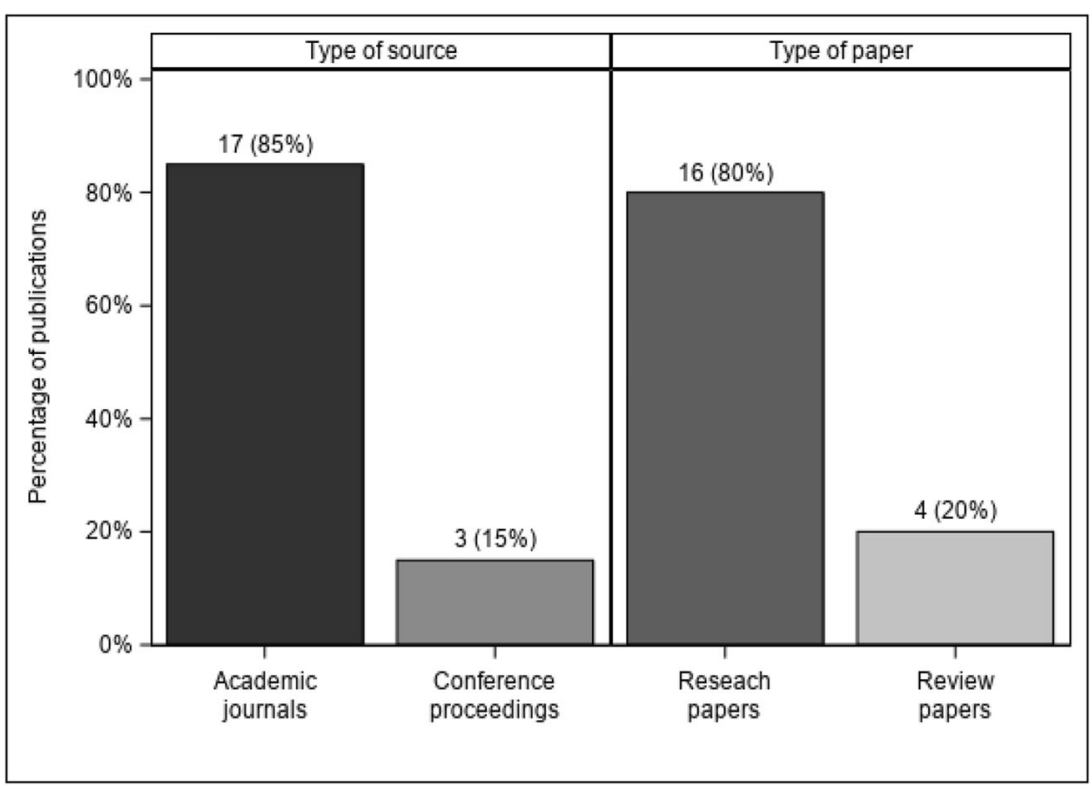


Fig. 4 LCC for UA papers by regions

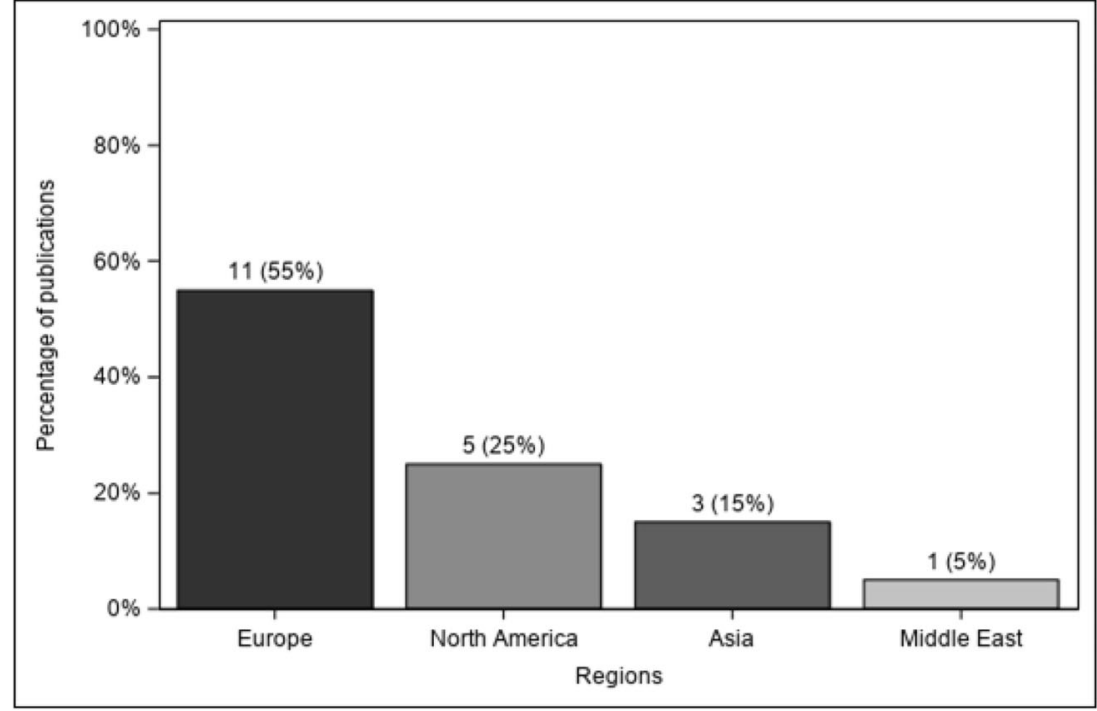

after the publication of the first standard: ISO (2008) containing the theoretical basis of this methodology. Most of the papers (6 publications or $30 \%$ ) were published in 2018 , followed by 2015 ( 5 publications or $25 \%$ ) and 2017, which had 3 publications or $15 \%$. In 2014 and 2016, 2 papers were published for each year, while in 2008 and 2009, we only found one paper per year. During the next four years (20102011-2012-2013), we did not find any publication.

According to the results, the most important year was 2015 because of the substantial increase in the publications, e.g. from zero, one or two papers in the first seven years to 5 in 2015. In 2016, we noticed a small decrease, but over the next two years (2017 and 2018), the number of publications increased notably; e.g. in 2018 , the growth was $15 \%$ compared with that of the previous year. From these results, we can conclude that the interest in using LCC for UA is increasing and that this tendency will probably continue in the coming years (Fig. 2).

Regarding the types of papers and their sources, we found that all the references were articles. Of the articles, 16 or $80 \%$ were original papers and 4 or $20 \%$ were review papers. Peerreviewed journals were the main source, accounting for $85 \%$ of the total number of references, while the remaining $15 \%$ were conference proceedings (Fig. 3).

By regions, Europe was the leading region with 11 articles or $55 \%$ of the total, followed by North America (Canada and USA) with 5 publications or $25 \%$. Asia had 3 papers (15\%), while the Middle East (Israel) had only one (Fig. 4).

Within the European region, Spain with 4 publications and Italy with 2 had a preeminent position over the rest of the countries which had only 1 publication (Fig. 5).
Fig. 5 LCC for UA papers by countries in the European region

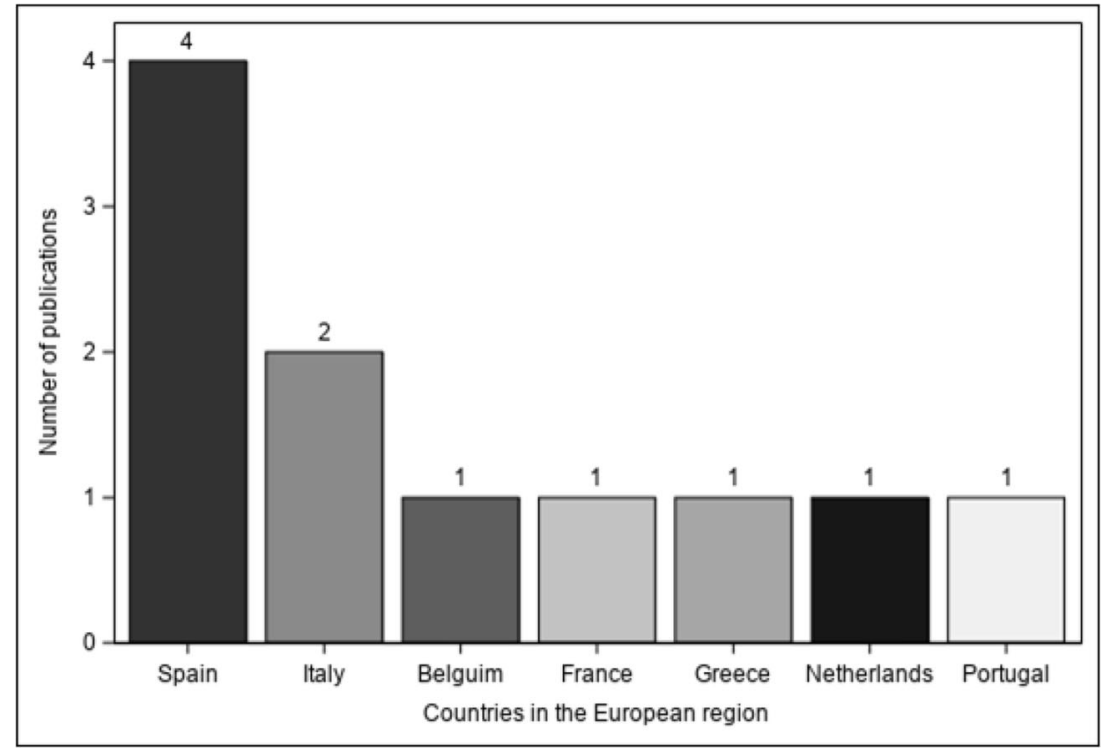


Table 2 Results by type of urban agricultural practice, research topic, LCC integration with LCA/S-LCA and LCC guidelines followed

\begin{tabular}{|c|c|c|c|c|}
\hline Reference & $\begin{array}{l}\text { Type of urban agriculture } \\
\text { practice }\end{array}$ & Research topic & $\begin{array}{l}\text { LCC integration with LCA/ } \\
\text { S-LCA }\end{array}$ & $\begin{array}{l}\text { LCC guidelines } \\
\text { followed }\end{array}$ \\
\hline Kim and Zhang (2018) & Aquaculture & Solar water heaters & Yes & ISO $15686-5(2017)$ \\
\hline Forchino et al. (2018 & Aquaponics & Indoor aquaponics system & & $\begin{array}{l}\text { Ciroth and Franze } \\
\text { (2009) }\end{array}$ \\
\hline Dorr et al. (2017) & Urban horticulture & Rooftop gardening practices & & ISO $15686-5(2008)$ \\
\hline $\begin{array}{l}\text { Llorach-Massana et al. } \\
\text { (2016) }\end{array}$ & & $\begin{array}{l}\text { Phase-change materials (PCM) for a solar } \\
\text { storage system }\end{array}$ & & \\
\hline $\begin{array}{l}\text { Sanyé-Mengual et al. } \\
\text { (2015a) }\end{array}$ & & Rooftop greenhouse & & \\
\hline $\begin{array}{l}\text { Sanyé-Mengual et al. } \\
\quad(2015 \mathrm{c})\end{array}$ & & Cultivation techniques and crops & & \\
\hline $\begin{array}{l}\text { Sanyé-Mengual et al. } \\
\text { (2018) }\end{array}$ & & Home gardening & & ISO 14040 (2006) \\
\hline Opher et al. (2018) & & Water reuse approaches & & $\begin{array}{l}\text { UNEP/SETAC } \\
\quad(2011)\end{array}$ \\
\hline Liaros et al. (2016) & & Urban indoor plant factory & No & Kishk et al. (2003) \\
\hline Benis et al. (2018) & & Productive uses of rooftops & & No described \\
\hline
\end{tabular}

\subsection{Group 1: application of the LCC methodology to different types of UA}

This first group included 10 papers (50\% of total selected) describing the application of LCC to different types of UA, e.g. home gardens, rooftop greenhouses and aquaponics systems. We analysed the papers in relation to 10 different comparison criteria that we grouped into three parts: (i) type of urban agricultural practice, research topic; LCC integration with LCA or S-LCA and LCC guildelines followed; (ii) system boundaries, functional unit, use of financial tools and additional analyses for assessment; (iii) type of LCC (conventional, environmental and societal) and costs used according to the life cycle stage.

\subsubsection{Type of urban agricultural practice, research topic, LCC integration with LCA/S-LCA and LCC guidelines followed}

Table 2 presents a summary of the results by type of urban agricultural practice, research topic, LCC integration with LCA/S-LCA and LCC guidelines followed.

In the literature, there are several basic urban agricultural practices: horticulture, aquaculture, livestock raising, forestry and other farming activities (Baumgartner and Belevi 2001).
Fig. 6 Type of urban agricultural practices

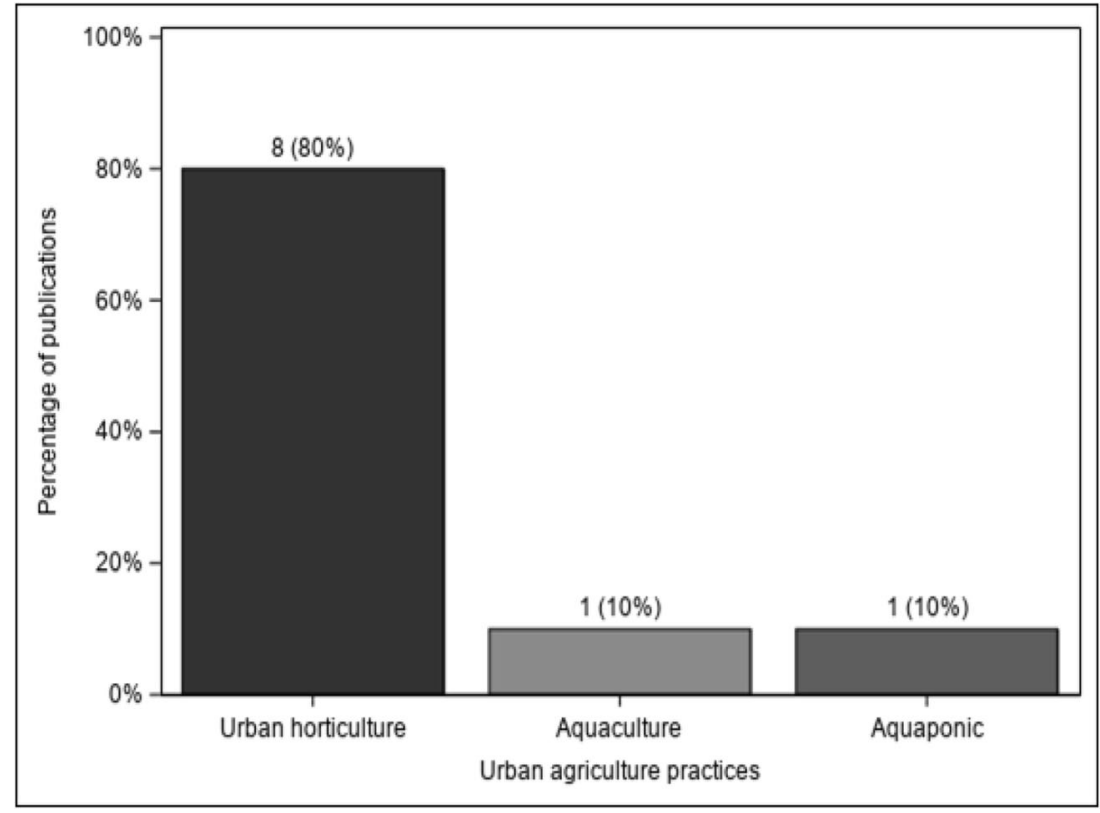


Fig. 7 Proportion between papers on the traditional forms and innovative forms of UA

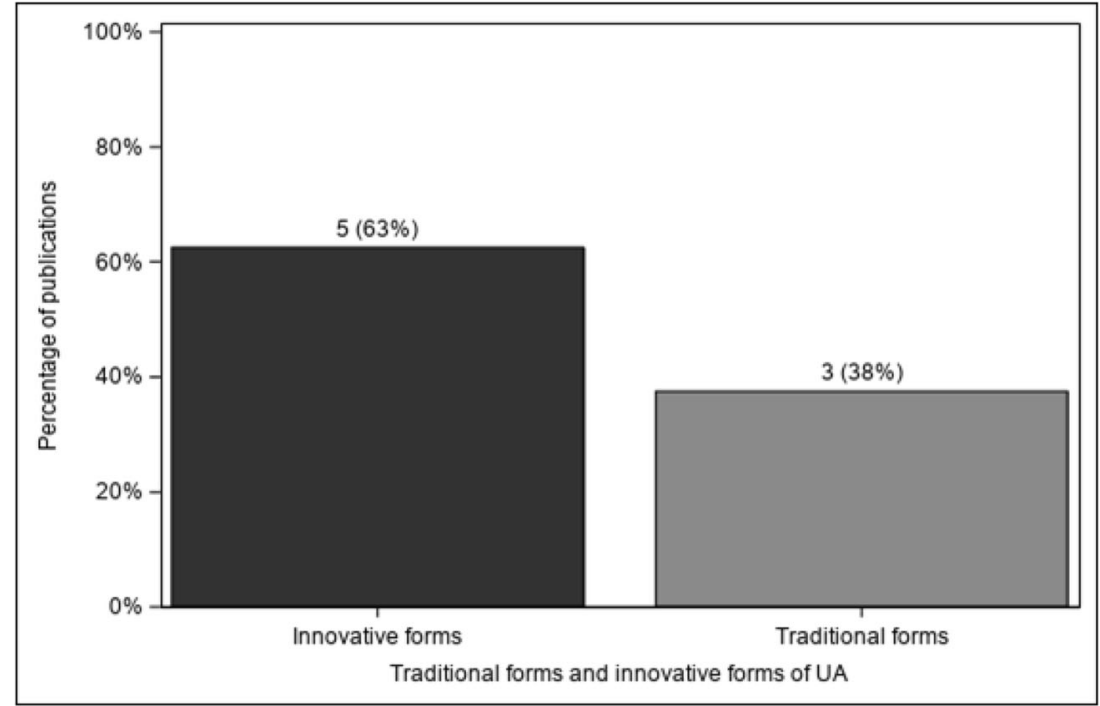

Urban horticulture related to the growth of vegetables or fruits was the most studied urban agricultural practice in 8 of the 10 papers in this group, while Kim and Zhang (2018) studied aquaculture (fish production), and Forchino et al. (2018) analysed an aquaponics system (fish and plants coproduction). Figure 6 displays these findings graphically.

To better illustrate these results, we classified the urban horticulture papers into two subgroups. In the first subgroup, 3 papers on traditional forms of UA, such as home gardens (Opher et al. 2018; Sanyé-Mengual et al. 2018) and multichannel greenhouses (Llorach-Massana et al. 2016), were included. The second subgroup comprised 5 papers on some innovative forms of UA, such as indoor farms (Liaros et al. 2016), rooftop greenhouses for open-air production (Benis et al. 2018), rooftop greenhouses (Sanyé-Mengual et al. 2015a) and rooftop gardens (Dorr et al. 2017; SanyéMengual et al. 2015c). All of these innovative forms are part of the building-integrated forms of UA, such as vertical farming or ZFarming and urban rooftop agriculture (URA). We placed 5 of the urban horticulture papers in the second group, while the remaining 3 were included in the first group. Figure 7 shows the proportion between papers on traditional forms and innovative forms of UA.

From this, we can state that the focus of the authors using LCC for UA in the studied period of 22 years (1996-2018) was mainly on the building-integrated forms of UA (indoor farms, rooftop greenhouses, rooftop gardens) rather than on the traditional ones (home gardens and multi-channel greenhouses).

We found different research topics in the 10 papers of group 1 .

Table 3 System boundaries and functional unit

\begin{tabular}{|c|c|c|}
\hline Reference & System boundaries approach & Functional unit \\
\hline Kim and Zhang (2018) & \multirow[t]{2}{*}{ Cradle-to-grave } & An additional $1000 \mathrm{~kg}$ of fish production \\
\hline Sanyé-Mengual et al. (2015a) & & $1 \mathrm{~m}^{2}$ of a greenhouse structure \\
\hline Forchino et al. (2018) & \multirow[t]{5}{*}{ Cradle-to-farm gate } & $1 \mathrm{~kg}$ of lettuce and fish considered as a co-product \\
\hline Dorr et al. (2017) & & $1 \mathrm{~kg}$ of tomatoes and lettuce \\
\hline Llorach-Massana et al. (2016) & & $1 \mathrm{~kg}$ of tomatoes \\
\hline Sanyé-Mengual et al. (2015a) & & \\
\hline Sanyé-Mengual et al. (2015c) & & $\begin{array}{c}1 \mathrm{~kg} \text { of lettuce, tomatoes, chilli peppers, } \\
\text { eggplants, melons, and watermelons }\end{array}$ \\
\hline Sanyé-Mengual et al. (2018) & \multirow[t]{2}{*}{ Cradle-to-consumer } & $1 \mathrm{~kg}$ of lefty and fruit vegetables \\
\hline Sanyé-Mengual et al. (2015a) & & $1 \mathrm{~kg}$ of tomatoes \\
\hline Benis et al. (2018) & \multirow{3}{*}{$\begin{array}{l}\text { Not described but a cradle-to-consumer } \\
\text { approach could be considered }\end{array}$} & $1 \mathrm{~m}^{2}$ of rooftop \\
\hline Opher et al. (2018) & & Annual supply, reclamation and reuse of water \\
\hline Liaros et al. (2016) & & $1 \mathrm{~kg}$ of sweet basil \\
\hline
\end{tabular}


From the 8 papers on urban horticulture practice, Liaros et al. (2016) evaluated the economic efficiency of urban indoor plant factories with artificial lighting as a business model, while Benis et al. (2018) compared two of the main uses of rooftops: urban food production and energy generation. Llorach-Massana et al. (2016) analysed the environmental and economic performance of the use of phase-change materials for a solar energy storage system used in a root zone to replace conventional root zone systems that depend on gas, oil or biomass. More specifically, they studied its application for improving the productivity of a multi-channel greenhouse. Opher et al. (2018) assessed the sustainability of four water reuse approaches for toilet flushing and garden irrigation in urban dwellings. The commonality among the 4 remaining papers was the analysis of the economic sustainability of urban food production (Sanyé-Mengual et al. 2018; Dorr et al. 2017; Sanyé-Mengual et al. 2015a,c). Sanyé-Mengual et al. (2018) investigated the environmental impacts and the economic costs of vegetables produced in a home garden in Padua (Italy), while Dorr et al. (2017) assessed the environmental and economic impacts of rooftop gardening practices on crop and substrate selection. Sanyé-Mengual et al. (2015a) estimated the environmental and economic performance of a rooftop greenhouse (RTG) in Barcelona in comparison with a multi-channel greenhouse in Almeria. Finally, SanyéMengual et al. (2015c) compared different cultivation techniques and crops. Regarding the papers on fish production, Kim and Zhang (2018) investigated solar water heaters for the improvement of fish production (aquaculture), whereas Forchino et al. (2018) quantified the environmental and economic impacts of the design of an indoor aquaponics system.

On the other hand, we noted that, of the 10 papers that formed the first group, only Liaros et al. (2016) and Benis et al. (2018) applied LCC in isolation from the other life cycle analyses. This means in general the authors preferred to combine the LCC analysis with LCA or S-LCA. The reason for this was perhaps that they wanted to illustrate the full picture of sustainability including the environment, economy and society. LCA and LCC analyses must be executed in the same way, e.g. the same system boundaries, functional units and allocation methods (Hunkeler et al. 2008). However, LCA and LCC can be correlated negatively or positively; i.e. financial feasibility does not mean environmental viability and vice versa (European Commission 2010).

With reference to the LCC guidelines followed, ISO (2008) was the most commonly used in 5 of the 10 papers (Dorr et al. 2017; Llorach-Massana et al. 2016; Sanyé-Mengual et al., 2015a and 2015c; Sanyé-Mengual et al. 2018), and the updated version, ISO (2017), was found in the publication by Kim and Zhang (2018). Other LCC guidelines, such as those by Ciroth and Franze (2009), were applied in the study by Forchino et al. (2018), while Liaros et al. (2016) used the following paper for this purpose: Whole life costing in construction: a state of the art review (Kishk et al.2003). Finally, only the guideline ISO (2006) was used for both LCA and LCC analyses in Sanyé-Mengual et al. (2018).

\subsubsection{System boundaries, functional unit, financial tools and additional analyses for assessment}

Table 3 shows a summary of the findings by system boundaries and functional unit.

We found three different approaches for assessment in relation to the system boundaries: cradle-to-grave, cradle-tofarm gate and cradle-to-consumer. Only Sanyé-Mengual et al. (2015a) applied all three assessment approaches. For example, they used a cradle-to-grave approach to estimate the cost of a greenhouse structure, while a cradle-to-farm gate analysis was carried out at the production stage, and finally, they applied a cradle-to-consumer approach at the consumption point. According to our results, the most widley procedure was a cradle-to-farm gate, which was found in five of the papers (Dorr et al. 2017; Forchino et al. 2018; LlorachMassana et al. 2016; Sanyé-Mengual et al. 2015a and

Table 4 Use of financial tools

\begin{tabular}{|c|c|}
\hline Reference & Financial tools \\
\hline $\begin{array}{l}\text { Benis et al. (2018) } \\
\text { Liaros et al. (2016) }\end{array}$ & $\begin{array}{l}\text { - Net present value (NPV) } \\
\text { - Internal rate of return (IRR)/Return on investment (ROI) } \\
\text { - Simple payback period (SPBP) }\end{array}$ \\
\hline $\begin{array}{l}\text { Benis et al. (2018) } \\
\text { Kim and Zhang (2018) }\end{array}$ & - Interest/discount rate $(\%)$ \\
\hline $\begin{array}{l}\text { Benis et al. (2018) } \\
\text { Llorach-Massana et al. (2016) }\end{array}$ & - Inflation rate $(\%)$ \\
\hline Kim and Zhang (2018) & - Escalation rate $(\%)$ \\
\hline Liaros et al. (2016) & $\begin{array}{l}\text { - Complete payback period (CPBP) } \\
\text { - Simple net present value (sNPV) } \\
\text { - Benefit-to-cost ratio (BCR) }\end{array}$ \\
\hline
\end{tabular}


2015c). In contrast, Sanyé-Mengual et al. (2018) used a cradle-to-consumer or cradle-to-fork approach, and Kim and Zhang (2018) applied a cradle-to-grave approach. The only exceptions were the publications by Liaros et al. (2016), Benis et al. (2018) and Opher et al. (2018), in which the system boundaries were not described but were considered to be a cradle-to-consumer approach.

Regarding the functional unit in urban horticulture papers, the most commonly used was $1 \mathrm{~kg}$, which was applied to harvested vegetables such as sweet basil (Liaros et al. 2016); leafy vegetables and fruits (Sanyé-Mengual et al. 2018); tomatoes (Llorach-Massana et al. 2016; Sanyé-Mengual et al. 2015a); tomatoes and lettuce (Dorr et al. 2017) and lettuce, tomatoes, chilli peppers, eggplants, melons and watermelons (Sanyé-Mengual et al. 2015c). In aquaculture, the functional unit in the study of Kim and Zhang $(2018$, p.47) is a special case expressed as an additional $1000 \mathrm{~kg}$ fish production (as a result of using hot water) per year over the course of 10 years. While in aquaponics, Forchino et al. (2018) used as a functional unit, $1 \mathrm{~kg}$ of produced lettuce and fish (tilapia) considered as a co-product. We also found functional units not related to vegetables or fish production. For example, in Benis et al. (2018), the functional unit was $1 \mathrm{~m}^{2}$ of rooftop used for food production or energy generation, whereas in Opher et al. (2018), it was the annual supply, reclamation and reuse of water consumed by a hypothetical city.

Various authors recommend the use of different financial tools to complement LCC analysis, such as net present value (NPV) (ISO 2008, Kim et al. 2015; Assad et al. 2015; Carter and Keeler 2008, Ammar et al. 2013; Vargas-Parra et al. 2014), internal rate of return (IRR) or return on investment (ROI) (Wong et al. 2003, Fuller and Petersen, 1996), payback period (PBP) (Farreny et al. 2011; ISO 2008; Koroneos and Nanaki 2012), inflation rate (Wong et al. 2003; Fuller and Petersen, 1996), break-event point (BEP) (Jeong et al.2015) and savingsto-investment ratio (SIR) (Jeong et al.2015; Wong et al. 2003; ISO 2008). Because of its importance, in this section, we present some of the examples we detected for the use of financial tools. We found that 4 of 10 papers applied additional financial tools. Table 4 presents a summary of these results.

For example, Liaros et al. (2016) used the following financial tools: simple payback period (SPBP), complete payback period (CPBP), NPV, simple net present value (sNPV), benefit-to-cost ratio (BCR) and return on investment (ROI). Benis et al. (2018) estimated a 50-year discounted cash flow (DCF) for rooftop systems through NPV, IRR and PBP. Discount rate (\%) and annual inflation (\%) were also included in their analysis. The inflation rate was also considered in Llorach-Massana et al. (2016). Finally, Kim and Zhang (2018) analysed the economic feasibility of solar heating. The financial tools used for this purpose were escalation rate (e) and interest/discount rate (i).

In many LCC studies, a sensitivity analysis was applied as an additional analysis for assessment (Carter and Keeler 2008;
Assad et al.2015, European Commission 2010). Its main purpose of this analysis is to show the effects of changing key assumptions in order to consider different possible results as a way of reducing uncertainty (ISO 2008). A sensitivity analysis was also used in 6 of the 10 examined papers (Kim and Zhang 2018; Liaros et al.2016, Sanyé-Mengual et al. 2015a, c; Llorach-Massana et al. 2016, Dorr et al.2017). For example, in the study by Kim and Zhang (2018), a sensitivity analysis was used to evaluate various inputs, such as electricity costs, the cost of thermal solar collectors, collector efficiency, retail fish price, number of initial fish stocks and choice of species. Liaros et al. (2016) used this analysis to identify which economic factors affected the performance of a plant factory as an investment option. Sensitivity analysis was also applied in the work of Sanyé-Mengual et al. (2015a) to illustrate how their results depended on crop yield and distance, while LlorachMassana et al. (2016) and Dorr et al. (2017) used this analysis to assess the type of scenario analysed. Finally, SanyéMengual et al. (2015c) assessed the availability of re-used elements and the use intensity of a rooftop garden through sensitivity analysis.

Other types of additional analyses for assessment were found in the publication by Sanyé-Mengual et al. (2018). They applied an eco-efficiency analysis to study the relationship between environmental impact and economic costs.

\subsubsection{Type of LCC and type of costs used by life cycle stage}

Three different types of LCC analyses exist: conventional, environmental and social (Hunkeler et al.2008; UNEP/SETAC 2011). Conventional LCC covers all costs internal to the organization, while external costs are included in both environmental and societal LCC. Environmental LCC addresses external environmental costs that are likely to be internalized for decisions in the near future (e.g. through carbon prices or taxes). Finally, societal LCC includes all further external costs related to specific scenarios on a societal level (Skovgaard et al. 2007) to examine welfare losses and gains associated with the re-allocation of resources (Møller et al. 2014). Our results indicated that only Benis et al. (2018) applied all three types of LCC.

Since LCC takes into consideration the costs and cash flows arising from design and acquisition from operation and maintenance through to disposal (ISO 2008, Wu and Longhurst 2011), four main stages should be included in the LCC analysis (Fuller and Petersen, 1996, Jeong et al. 2015, Kim et al. 2015, Koroneos and Nanaki 2012, Sanyé-Mengual et al. 2015a, Vargas-Parra et al. 2014).

- Initial or construction stage, where initial investment costs are included

- Operation stage, involving all costs accrued during the usage of the asset 
Table 5 Type of costs used by life cycle stage

Reference Costs included by life cycle stage

Costs not included

\begin{tabular}{|c|c|c|}
\hline & \\
\hline & Initial/construction & Operation \\
\hline $\begin{array}{l}\text { Kim and Zhang } \\
\text { (2018) }\end{array}$ & $\begin{array}{l}\text {-Technical installations: solar } \\
\text { water heating system }\end{array}$ & $\begin{array}{l}\text {-Annual operation and mainter } \\
\text { heating system) } \\
\text {-Maintenance costs (auxiliary }\end{array}$ \\
\hline $\begin{array}{l}\text { Forchino et al. } \\
\text { (2018) }\end{array}$ & $\begin{array}{l}\text {-Infrastructure: building cost } \\
\text {-Technical installations: } \\
\text { aquaponics production } \\
\text { system }\end{array}$ & $\begin{array}{l}\text {-Production inputs: plants, } \\
\text { water, energy, fish feeds }\end{array}$ \\
\hline $\begin{array}{l}\text { Benis et al. } \\
\quad(2018)\end{array}$ & $\begin{array}{l}\text {-Infrastructure: greenhouse } \\
\text { structure }\end{array}$ & $\begin{array}{l}\text {-Production inputs: plants, } \\
\text { water, energy, organic } \\
\text { fertilizer, labour }\end{array}$ \\
\hline $\begin{array}{l}\text { Opher et al. } \\
\text { (2018) }\end{array}$ & $\begin{array}{l}\text {-Technical installations: } \\
\text {-Water reuse system }\end{array}$ & $\begin{array}{l}\text {-Electricity } \\
\text {-Seawater desalination costs }\end{array}$ \\
\hline $\begin{array}{l}\text { Sanyé-Mengual } \\
\text { et al. (2018) }\end{array}$ & $\begin{array}{l}\text {-Technical installations: } \\
\text { cultivation and irrigation } \\
\text { system }\end{array}$ & $\begin{array}{l}\text {-Production inputs } \\
\text {-Distribution transport } \\
\text {-Gardener transport } \\
\quad \text { (purchase of materials) }\end{array}$ \\
\hline Dorr et al. (2017) & & -Tap water \\
\hline
\end{tabular}

Maintenance End-of-life

Dorr et al. (2017)

-Tap water

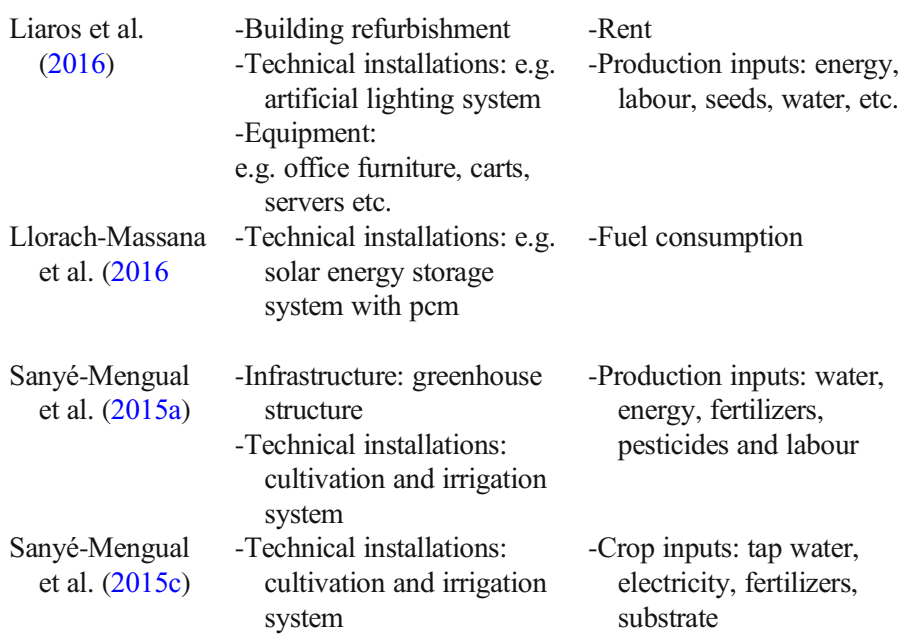

$-$

ance costs (solar water

electric water heater)

-
-Replacement costs of
materials and
equipment

-Transportation to the recycling plant

-Labour cost

-Dismantling costs

-Recycling costs of water and materials
-Rooftop garden installation (construction)
-Infrastructure maintenance
-Labour cost

-Maintenance costs
(building and
technical
installations)

-Replacement costs of
technical installations
-Labour for basic
maintenance
-Maintenance costs
(infrastructure)
-Dismantling costs of building installations

-End-of-life costs
- Maintenance stage, which consists of the costs of repair and replacement and

- End-of-life (EoL) stage, comprising the decommissioning/ dismantling, demolition, disposal and recycling costs.

Table 5 shows the results of type costs used by each life cycle stage. This table also shows (in the last column) those costs that were not included in the LCC analysis:

- Initial or construction stage: rooftop garden installation

- Operation stage: labour costs
- Maintenance stage: infrastructure maintenance, replacement costs

- End-of-life (EoL) stage: recycling costs

Table 6 Papers on costs reduction

\begin{tabular}{lc}
\hline Reference & Costs to be optimized \\
\hline $\begin{array}{l}\text { Zidar et al. (2017) } \\
\text { Zhao and Meng (2014) }\end{array}$ & Operation and maintenance costs \\
Halwatura and Jayasigne (2009) & $\begin{array}{c}\text { Initial capital cost } \\
\text { (initial/construction stage) }\end{array}$ \\
\hline
\end{tabular}


Table 7 Literature review of papers on LCC addresing various topics related to the UA

\begin{tabular}{|c|c|c|}
\hline Reference & Type of urban horticulture & Findings \\
\hline Benis and Ferrão (2018) & Commercial farming & $\begin{array}{l}\text { High construction costs of the urban commercial farms in comparison with } \\
\text { conventional and rural farms } \\
\text { Elevated operation costs due to the lack of subsidies (e.g. water, energy) }\end{array}$ \\
\hline Nguyen and Weiss (2008) & Vertical farms & $\begin{array}{l}\text { Construction and operation costs depend on location, market, season, demand, } \\
\text { supply, energy costs and many other factors } \\
\text { The construction time and overall costs could be minimised by reducing the } \\
\text { waste in construction and reasonable use of resources } \\
\text { An appropriate design for the end-life stage would lead to construction techniques } \\
\text { for decreasing whole life-cycle costs }\end{array}$ \\
\hline $\begin{array}{l}\text { Sanyé-Mengual et al. (2015b) } \\
\text { Sanyé-Mengual et al.(2017) }\end{array}$ & Urban rooftop agriculture (URA) & $\begin{array}{l}\text { Open-air rooftop gardens have lower economic costs than rooftop greenhouses } \\
\text { Decisions in the design phase/initial or construction stage of URA (cultivation } \\
\text { technique, crop choice and management) are important for improving its } \\
\text { economic sustainability }\end{array}$ \\
\hline
\end{tabular}

These results are especially significant because for the first time they reveal that essential costs, like labour or the initial investment, are frequently not included. As we discuss later (see "Discussion" section), this is a weakness on the LCC application to UA.

\subsection{Group 2: papers on cost reduction}

In this section, we present the results from 3 other research papers that have optimized costs. They also used LCC for this purpose (Table 6).

The objective of Zidar et al. (2017) was to present a decision-support tool for green infrastructure (GI) systems to improve urban ecosystem services in Camden, USA. The authors analysed the possibility for expansion of UA through community gardens. They examined the possibility of life cycle cost reduction by looking for new funding sources for the vacant lots located at the intersection of Vine and Willard in North Camden, USA. The authors confirmed that local people involved in various green garden programmes could reduce the operation and maintenance life cycle costs.
Zhao and Meng (2014) analysed the operation costs, including the running maintenance costs, of the construction of agricultural water-saving facilities in Tianjin, China. Based on the life cycle cost theory, they found that designing innovation is the key to controlling the complex operation costs. Additionally, they investigated the effect of the investment and financing model on the design innovation process because, on the one hand, the manner of investment and financing can help to solve the construction-funding gap, whereas on the other hand, it will alter water-saving costs.

The last paper in this group, Halwatura and Jayasigne (2009), aimed to determine the ways in which an insulated roof slab could affect the energy needs for air conditioning in Sri Lanka and considered its influence on the life cycle costs. Despite the fact that this paper was related more to the construction and building sector, it was strongly connected with UA because of the opportunity for the creation of rooftop gardens to minimize the initial capital cost of the insulated roof slabs. The insulated roof slabs were expected to have additional benefits in comparison with those of a conventional roofing system, such as better cyclone resistance, low maintenance and the ability to create a greener environment with a rooftop garden. According to the authors, there was a

Table 8 Other papers on costs for UA

\begin{tabular}{|c|c|c|c|}
\hline Reference & Urban agricultural practice & Limitations & Costs included \\
\hline Love et al. (2015) & Aquaponics & \multirow{2}{*}{$\begin{array}{l}\text { The infrastructure/capital cost } \\
\text { (initial/construction stage) } \\
\text { and the labour cost (operation stage) } \\
\text { were not included }\end{array}$} & $\begin{array}{l}\text { Production/operation costs: } \\
\text { energy, water, fish feed }\end{array}$ \\
\hline Algert et al. (2014) & $\begin{array}{l}\text { Urban horticulture: community } \\
\text { gardens }\end{array}$ & & $\begin{array}{l}\text { Production/operation costs: } \\
\text { plants, seed, fertilizers, tools and soil } \\
\text { amendment }\end{array}$ \\
\hline $\begin{array}{l}\text { CoDyre et al. } \\
\text { (2015) }\end{array}$ & Urban horticulture: home gardens & $\begin{array}{l}\text { Only one city was investigated } \\
\text { Drought and above-average } \\
\text { temperatures, which affected the produc- } \\
\text { tivity }\end{array}$ & $\begin{array}{l}\text { Infrastructure/capital cost } \\
\text { Operation costs: } \\
\text { land and labour }\end{array}$ \\
\hline
\end{tabular}


significant reduction in the slab top temperature, with the presence of rooftop vegetation leading to energy savings, which was considered in the life cycle analysis.

\subsection{Group 3: literature review of papers on LCC addresing various topic related to UA}

In this section, we analysed 4 other papers that were literature reviews addressing various topics related to UA, including life cycle costs (Benis and Ferrão, 2018; Nguyen and Weiss 2008; Sanyé-Mengual et al. 2017; Sanyé-Mengual et al.2015 b) (Table 7).

The first paper aimed to analyse the environmental, economic and social aspects of urban commercial farming as a part of urban horticulture based on case studies in northern Europe (Benis and Ferrão 2018). The authors examined two main points regarding the economic aspects of urban commercial farming: the level of investment and operation costs versus productivity. They confirmed that the capital expenditures of commercial farms are higher in comparison with those of conventional and rural farms and that the existence of prohibitive rents and high construction costs also reflect these results. According to the authors, the reason for the elevated operating costs was their high-energy needs and the lack of municipal subsidies (e.g. energy and water subsidies). Despite the higher costs, they demonstrated that the benefits of urban commercial farms could be found in the shortened supply chain where the logistics costs were reduced and the added value of the fresher product may have justified a higher selling price.

Nguyen and Weiss (2008) analysed vertical urban farms' systems considering life cycle costs, design, construction, operation and infrastructure integration for environmental management and residences. The authors explained that construction and operation costs and revenues varied tremendously depending on location, market, season, demand, supply, energy costs and many other factors. According to the authors, waste reduction in construction and rationalized use of construction resources can decrease the construction time and thus decrease the overall costs. The selection of an appropriate design for the end-of-life stage could also lead to construction techniques for reducing the whole life cycle costs.

The literature review of Sanyé-Mengual et al. (2017) was based on an updated version of their previous work presented during the 7th International Aesop Sustainable Food Planning Conference in Torino, Italy (Sanyé-Mengual et al. 2015b). Sanyé-Mengual et al. (2017) used an interdisciplinary approach to evaluate different topics related to the sustainability of URA, including its environmental impacts and economic costs. The environmental impacts were evaluated by LCA, and the economic costs were evaluated through LCC. They analysed three case studies for this purpose: a rooftop greenhouse (RTG) in Bellaterra, Spain; a community rooftop garden (CRG) in Bologna, Italy and a private rooftop garden (PRG) in
Barcelona, Spain. In comparison with the rooftop greenhouses, for open-air rooftop gardens, they found lower environmental impacts and economic costs. As for the design phase of URA, the LCC and LCA results accentuated the possible contribution of URA products in improving both economic and environmental sustainability. The LCA and LCC results also highlighted the importance of the decisions made in the design phase in relation to the cultivation technique, crop choice and management.

\subsection{Group 4: other papers on costs for UA}

The last group is formed of 3 research papers that calculated costs for UA without specification of the methodology used. Table 8 presents a summary of the results by type of urban agricultural practice, limitations and costs included.

In the first paper, Love et al. (2015) analysed a small-scale raft aquaponics system in Baltimore (USA) to explain the operating conditions as production inputs (energy, water, and fish feed) and outputs (edible crops and fish) and their relationship. The main limitation of the study was that the authors did not consider the infrastructure/capital and the labour costs for the analysis. Other operation/production costs, such as the costs of energy, water, and fish feed, were included. The results show that raising fish created a net loss, while crop cultivation presented a net gain when comparing market prices to energy costs.Accordingly, the authors suggested that new approaches for minimizing heating for fish should be found or that new species able to survive at lower water temperatures should be used.

Algert et al. (2014) investigated the capacity of community gardens to affect food affordability in an urban setting by documenting the vegetable outputs and cost savings of community gardens in the city of San Jose, California (US). The system boundaries were limited to the production stage, excluding labour and infrastructure/capital costs. The authors calculated the economic cost by quantifying the following inputs needed for production: seeds, fertilizers, tools and soil amendments. The results of the study revealed that the vertical growth of high-yield, higher-value vegetables such as tomatoes, cucumbers, and peppers, can provide greater cost savings relative to the cost of purchasing the same amount of vegetables in a retail setting.

Finally, in the last paper, CoDyre et al. (2015) presented the results of a preliminary survey aimed at evaluating the productivity of urban gardens in the medium-sized Canadian city of Guelph. All gardens analysed were home gardens in private yards that included backyard plots and community garden spaces. The main limitation of the study was that only one city was investigated. Moreover, the analysed gardening season was subject to drought and above-average temperatures, which affected productivity. The survey aimed to assess the productivity of urban gardens in terms of land, labour and capital. Different policy outcomes were also evaluated to 
promote the potential of urban gardening. The results showed that, on average, tomatoes represented $37 \%$ of all harvests, followed by potatoes at $12 \%$ and squash at $7 \%$. The authors found that the level of production and input costs varied widely across gardeners and that there was great potential in urban self-provisioning. They suggested two main methods for improving self-provisioning among the gardeners: putting more land into production and improving the gardener's skills.

\section{Discussion}

In this section, we discuss the 4 most relevant findings from the "Results" section: (i) type of urban agriculture practice from group 1 and group 3; (ii) LCC integration with LCA/SLCA from group 1; (iii) use of financial tools from group 1 and (iv) type of costs used at each life cycle stage from group 1 , group 2 and group 4 . We considered these findings the most important for the following reasons: (i) all of them are part of group 1, the major group consisting of 10 papers or $50 \%$ of 20 selected references; (ii) the most studied type of urban agriculture practice (horticulture) is important because it provides information for future directions of research of LCC in UA and finally, (iii) the life cycle stages are a fundamental part of the LCC methodology (ISO 2008); in this respect, the discussion on the type of costs used by life cycle stage is relevant.

Taking into account the importance of these findings, we present a discussion of each of them as follows:

- Type of urban agriculture practice

- LCC integration with LCA/S-LCA

- Use of financial tools

- Type of costs used by life cycle stage

\subsection{Type of urban agricultural practice}

The results of "3.2.1. Type of urban agricultural practice, research topic, LCC integration with LCA/S-LCA and LCC guidelines followed" (group 1) indicated that the most studied urban agricultural practice related to LCC was urban horticulture in 8 of the 10 papers. Urban horticulture was also analysed by all the authors in "Group 3: literature review papers on life cycle cost addresing various topics related to UA" (see Table 7). This result was not surprising because Parece et al. (2016) stated that, among plant and animals used for food, the plant production represented by urban horticulture was predominant.

Within urban horticulture studies, the building-integrated forms of UA such as vertical farming or zero-acreage farming (ZFarming), including indoor farms, rooftop greenhouses, rooftop gardens and further innovative forms, are becoming more popular. The main reason for this is the insufficient space for traditional ground agriculture in many urban cities and the lack of resources needed for production, such as water and energy (Specht et al.2014; Thomaier et al.2015). We found clear examples of some innovative forms of UA that use advanced technology for resource optimization in SanyéMengual et al. (2015a) and Benis et al. (2018). For example, Sanyé-Mengual et al. (2015a) analysed the environmental and economic performances of a rooftop greenhouse (RTG) that took advantage of its integration into a sustainable building for optimizing water and energy consumption. Benis et al. (2018) evaluated the economic sustainability of high-tech rooftop greenhouse (RG) farms. Based on these results, we expect that the growing interest in innovative building-integrated forms of UA will continue in the future since the urbanization process is unavoidable (UN DESA, 2004). In light of this, we determined that more use and LCC research for UA is needed to evaluate the economic sustainability of these increasing building-integrated forms of UA.

\subsection{LCC integration with LCA/S-LCA}

One of the major findings of our study is the secondary role of LCC in its integration with LCA. Our results show that 9 of the 10 analysed papers in group 1 included both LCA and LCC analyses.

In all cases, LCA was the principal methodology, with LCC clearly playing just a secondary role. This was based on 4 of 10 studies (Forchino et al., 2018; Sanyé- Mengual et al. 2018; Dorr et al. 2017; Sanyé-Mengual et al. 2015c) where the environmental impact through LCA was extensively studied through LCA but the economic evaluation by LCC was incomplete. One possible explication for the insufficient LCC analysis was the fact that the authors' main background was in environmental sciences, meaning that they had relatively less expertise in cost accounting. Since we found that the proportion of the three analyses (LCA, LCC and S-LCA) comprising LCSA was not equivalent, special attention should be paid to the use of LCC within the LCSA framework. Therefore, we strongly recommend that future works apply the three types of assessments equally, i.e. LCA, LCC and S-LCA methods should have the same or similar weight (e.g. 33\% for each type of analysis) to make more balanced decisions for the improvement of sustainability in the UA context. It is also worth mentioning that only 1 of the 10 papers, Benis et al. (2018) applied LCC analysis at each level (conventional, environmental and societal).

\subsection{Use of financial tools}

Many authors have suggested the use of financial tools to complement LCC analyses such as NPV (ISO 2008; Kim et al. 2015; Assad et al. 2015; Vargas-Parra et al. 2014), IRR (Wong et al. 2003; Fuller and Petersen, 1996) and PBP 
(Farreny et al. 2011; ISO 2008; Koroneos and Nanaki 2012). Since we found that only 4 of 10 analysed papers in group 1 used these additional financial tools, we strongly recommend the use of financial tools in future research.

\subsection{Type of costs used by life cycle stage}

The life cycle sustainability framework is based on the assessment of environmental, economic and social impacts of a product, project or service in all life cycle stages. From our thorough review of the literature from the last decade (before 2008 we did not find any publication using LCC for UA), we can state that there is very poor use of life cycle stages when calculating the cost of UA. It was a difficult task to identify how the authors classified costs in each of the LCC stages, especially at the construction and operation stages. The main reason for this is that some authors used their own classification when referring to the life cycle stages for both LCA and LCC. It seems that little attention has been paid to this part of LCC analysis until now. In our opinion, the lack of classification of costs in the life cycle stages is not irrelevant because it impedes the comparison between similar studies of UA. Our results show that only Benis et al. (2018); Liaros et al. (2016) and Sanyé-Mengual et al. (2015a) included all four LCC stages: construction, operation, maintenance and end-of-life. Although ISO (2008) does not require all stages to be included, we consider that, for the progress of UA and its contribution to the sustainability of cities, it is necessary to know the complete cost, that is, including all four stages, when using LCC analysis; otherwise, the information generated will not be sufficient for decision-making.

Despite the difficulty in identifying each LCC stage in the analysed literature, following our argument on the relevance of the stages, we present a discussion of the type of costs used by life cycle stage (construction, operation, maintenance and end-of-life) based on the results derived from 16 papers from group 1, group 2 and group 4.

\subsubsection{Initial or construction stage}

The initial or construction stage of LCC includes the initial investment costs (Jeong and Lee 2009; Kim et al. 2015; Wu and Longhurst 2011; ISO 2008). These costs could be the costs of infrastructure, project design or taxes on construction goods or services, among many others (ISO 2008). Some authors also used the term capital cost when referring to these costs (Halwatura and Jayasigne 2009; Love et al. 2015).

In the case of UA, the initial investment costs are (i) the infrastructure, e.g. the greenhouse structure (Benis et al. 2018; Sanyé-Mengual et al. 2015a); (ii) the technical installations; e.g. the aquaponic production system (Forchino et al. 2018), cultivation system and irrigation system (Dorr et al., 2017; Sanyé-Mengual et al. 2018; Sanyé-Mengual et al. 2015a, c), solar water heating system (Kim and Zhang 2018) and artificial lighting system (Liaros et al., 2016) and (iii) other equipment, such as office furniture, carts and servers (Liaros et al., 2016).

From the 16 papers analysed in groups 1, 2 and 4, we identified 4 papers ( $25 \%$ of the total analysed) that did not contain them or some important costs such cost of infrastructure were not included. This was because some authors such Love et al. (2015) did not disclose the available information about the initial costs, or the cost of the infrastructure (rooftop garden) was not considered due to study constraints as in Dorr et al. (2017).

Based on this result, in our opinion, not including costs at the construction stage, especially the cost of infrastructure, is a big hurdle in the use of LCC analysis for UA. As we mentioned, we assume that the growing interest in innovative building-integrated forms of UA will continue in the next few years, so information about initial investment costs is very important in making decisions for implementing or not implementing these new systems on a large scale.

\subsubsection{Operation stage}

The operation stage of LCC comprises all operation costs accrued during the usage of the asset (ISO 2008, Jeong et al.2015; Jeong and Lee 2009; Wu and Longhurst 2011). Regarding UA, we identified the following operation costs: rent (Liaros et al., 2016); production inputs or crop inputs such plants or seeds (Forchino et al. 2018; Benis et al. 2018; SanyéMengual et al. 2018; Dorr et al. 2017; Sanyé-Mengual et al. 2015a), water and energy (Kim and Zhang 2018; Forchino et al. 2018; Benis et al. 2018; Opher et al. 2018; SanyéMengual et al. 2018; Dorr et al. 2017; Liaros et al. 2016, Sanyé-Mengual et al. 2015a; Love et al. 2015; LlorachMassana et al., 2016), labour (Benis et al. 2018; Liaros et al. 2016; Llorach-Massana et al., 2016; Sanyé-Mengual et al., 2015a) and finally distribution and gardener transport (Sanyé-Mengual et al. 2018).

A surprising finding within the operation stage was that only 5 or $31 \%$ of the 16 analysed papers (groups 1, 2 and 4) included the labour costs. The main reasons authors did not account for them were as follows: (i) it was not considered relevant; (ii) there was a lack of information (Love et al. 2015) and (iii) there was concern about the increase in the total cost when labour was included (Algert et al. 2014).

However, some authors strongly recommended the inclusion of labour costs at the operation stage. For example, Woodward (1997) classified labour as the main operation cost, while Lu et al. (2017) stated that labour costs were an important factor and that its exclusion was the main reason for the incomplete LCC analyses in some studies. Finally, SanyéMengual et al. (2015a) also demonstrated that labour was the 
most significant operation cost when analysing the economic performance of a rooftop greenhouse (RTG) in Barcelona.

We also agree that labour costs should be considered in the use of LCC for UA. We think that this condition is necessary for improving the LCC analysis in the UA context. The main argument is that labour is an important production factor in addition to raw materials and utilities (i.e. energy and water) (Baumgartner and Belevi 2001). The principal objective of UA is to produce and provide plants and animals for food; in this respect, labour is an essential part of this production process.

\subsubsection{Maintenance and end-of-life stages}

Repair and replacement costs are included at the maintenance stage, while the end-of-life (EoL) stage consists of decommissioning/dismantling, demolition, disposal and recycling costs (Fuller and Petersen, 1996; ISO 2008; Jeong et al. 2015).

Replacement or repair costs of construction materials and installations at the maintenance stage were considered in 8 of the 16 papers (Kim and Zhang 2018; Benis et al. 2018; Opher et al. 2018; Liaros et al. 2016; Llorach-Massana et al.2016; Sanyé-Mengual et al. 2015a; Zidar et al. 2017; Zhao and Meng 2014). Regarding the EoL stage, 7 of the 16 papers included or studied these costs. For example, dismantling costs of greenhouse structures were included in Benis et al. (2018), while Liaros et al. (2016) included these costs for building installations necessary for an urban indoor farm. In Sanyé-Mengual et al. (2015a), the cost of transport of infrastructure waste (rooftop greenhouse) to a recycling plant was considered, while Sanyé-Mengual et al. (2015c) included this cost for cultivation materials. Finally, Dorr et al. (2017) considered the recycling costs of water and materials.

The two main reasons authors did not account for the maintenance and end-of-life costs were (i) the lack of information about them (Llorach-Massana et al. 2016) and (ii) that they do not consider them relevant because these costs were times lower than initial/construction or operation costs (Opher et al. 2018).

Given that the lack of information is a recurrent reason for not including costs, we suggest future research to consider both maintenance and end-of-life costs for more complete LCC for UA. This is primarily because Lu et al. (2017) explained that disposal and demolition costs, as well as labour costs, are important factors and that their not inclusion is the main reason for insufficient LCC analysis. As for the maintenance costs, we presume that the importance of these costs will increase in the future because of their dependency on construction costs. In this regard, including maintenance costs should also be a requirement in future research.

\section{Conclusions}

The aim of this research was a literature review of the use of LCC methodology for the UA sector and its evolution over a period of 22 years beginning in 1996 and ending in July 2018. For this purpose, we accurately reviewed 20 selected references.

This paper is a significant contribution to the field because it is the first literature review ever performed on the use of LCC in the UA context. We think that it can contribute to the advancement of the balance of the application of LCC within the life cycle sustainability assessment framework.

The scope of this research was limited to papers related to urban food production (edible plants and animal rearing), while other agricultural activities, such as the production and sale of agricultural inputs, post-harvesting, marketing and commercialization of agricultural production, were excluded from the analysis. On the basis of this constraint, future research could attempt to investigate other UA activities.

The main finding of this research was the complementary role of LCC in its integration with LCA. The key analysis was always LCA, with LCC being secondary. Our results also show that LCC analysis was quite incomplete regarding the costs considered in each life cycle stage. We found that $25 \%$ of 16 analysed papers (groups 1,2 and 4) did not include costs at the initial/construction stage nor some important costs such cost of infrastructure were not considered. At the operation stage, labour cost, the principal cost of operations, was mainly ignored in 11 , or $69 \%$, of the 16 papers from groups 1,2 and 4 . As well as this, the costs at the maintenance and end-of-life stages were also generally excluded by authors. Only three authors accurately classified the costs by LCC stage (Benis et al. 2018; Liaros et al., 2016; Sanyé-Mengual et al. 2015a), which we consider the basic characteristic of LCC analysis. Additionally, since we found that only Benis et al. (2018) applied all three types of LCC (conventional, environmental and societal), we can conclude that the use of LCC analysis for $\mathrm{UA}$ is still in its early stages.

On the basis of these deficiencies, firstly, we strongly recommend future works to apply both LCA and LCC analyses at the same level. To accomplish this, LCC should be performed by people with relatively more expertise in cost accounting. Secondly, the inclusion of costs at the initial or construction stage is a necessary condition in order to improve the current use of LCC for UA and to evaluate its economic sustainability. Special attention needs to be paid to the labour costs at the operation stage, as it is an essential part of the production process. To this effect, lack of information should not be a pretext for not including essential costs.

Finally, all four main LCC stages should be considered in future research for more complete LCC analyses for UA. The use of additional financial tools, such as net present value 
(NPV), internal rate of return (IRR) and payback period (PBP), would be advisable to complement LCC analysis.

Acknowledgements This work is part of the Fertilecity II project supported by the Spanish Ministry of Economy and Competitiveness (CTM2016-75772-C3-1-R, AEI/FEDER, UE), from the Spanish Ministry of Science, Innovation and Universities through the María de Maeztu program for Units of Excellence (MDM-2015-0552). The authors give thanks to the Spanish Ministry of Economy and Competitiveness (MINECO) for awarding a research scholarship (BES-2016-079119) to Alexandra Mario Pena.

Open Access This article is licensed under a Creative Commons Attribution 4.0 International License, which permits use, sharing, adaptation, distribution and reproduction in any medium or format, as long as you give appropriate credit to the original author(s) and the source, provide a link to the Creative Commons licence, and indicate if changes were made. The images or other third party material in this article are included in the article's Creative Commons licence, unless indicated otherwise in a credit line to the material. If material is not included in the article's Creative Commons licence and your intended use is not permitted by statutory regulation or exceeds the permitted use, you will need to obtain permission directly from the copyright holder. To view a copy of this licence, visit http://creativecommons.org/licenses/by/4.0/.

\section{References}

Ackerman K, Conard M, Culligan P, et al (2014) Sustainable food systems for future cities: the potential of urban agriculture. Econ Soc Rev (Irel) 45:189-206 https://wwwesrie/article/view/136 Accessed 04 December 2018

Algert SJ, Baameur A, Renvall MJ (2014) Vegetable output and cost savings of community gardens in San Jose, California. J Acad Nutr Diet 114:1072-1076. https://doi.org/10.1016/j.jand.2014.02. 030

Ammar M, Zayed T, Moselhi O (2013) Fuzzy-based life-cycle cost model for decision making under subjectivity. J of Constr Eng M 139: 556-563. https://doi.org/10.1061/(ASCE)CO.1943-7862.0000576

Artmann M, Sartison K (2018). The role of urban agriculture as a naturebased solution: a review for developing a systemic assessment framework. Sustain 10:0-32. https://doi.org/10.3390/su10061937

Assad M, Hosny O, Elhakeem A, El Haggar S (2015) Green building design in Egypt from cost and energy perspectives. Archit Eng Des Manag 11:21-40. https://doi.org/10.1080/17452007.2013.775100

Baud ISA (2000) Collective action, enablement, and partnership: issues in urban development http://wwwuclacuk/dpu-projects/drivers urb_change/urb_governance/pdf_partic_proc/IHS_Baud_ collective actionpdf Accessed 04 December 2018

Baumgartner B, Belevi H (2001). A systematic overview of urban agriculture in developing countries. EAWAG/SANDE Dübendorf: 1$34 \mathrm{http}: / /$ wwwurbano-zeleniloorg/wp-content/uploads/ MATERIJALI\%20ZA\%20WEB/INOSTRANI/A_Systematic_ Overview_of_Urban Agriculture in Developing Countries\%20pdf Accessed 15 September 2019

Benis K, Ferrão P (2018) Commercial farming within the urban built environment - taking stock of an evolving field in northern countries. Glob Food Sec 17:30-37. https://doi.org/10.1016/j.gfs.2018. 03.005

Benis K, Turan I, Reinhart C, Ferrão P (2018) Putting rooftops to use - a cost-benefit analysis of food production vs. energy generation under Mediterranean climates. Cities 78:166-179. https://doi.org/10.1016/ j.cities.2018.02.011
Carter T, Keeler A (2008) Life-cycle cost-benefit analysis of extensive vegetated roof systems. J Environ Manag 87:350-363. https://doi. org/10.1016/j.jenvman.2007.01.024

Cerón-Palma I, Sanyé-Mengual E, Oliver-Solà J, Montero JI, Rieradevall $\mathrm{J}$ (2012) Barriers and opportunities regarding the implementation of Rooftop Eco. Greenhouses (RTEG) in Mediterranean cities of Europe. J Urban Technol 19:87-103. https://doi.org/10.1080/ 10630732.2012.717685

Ciroth A, Franze J (2009) Life cycle costing in SimaPro. GreenDeltaTC, Berlin https://wwwto-beit/wp-content/uploads/2015/07/ LCCinSimaPro_englishpdf Accessed 04 December 2018

CoDyre M, Fraser ED, Landman K (2015) How does your garden grow? An empirical evaluation of the costs and potential of urban gardening. Urban For Urban Green 14:72-79. https://doi.org/10.1016/j. ufug.2014.11.001

Dorr E, Sanyé-Mengual E, Gabrielle B, Grard BJ, Aubry C (2017) Proper selection of substrates and crops enhances the sustainability of Paris rooftop garden. Agron Sustain Dev 37:51. https://doi.org/10.1007/ s13593-017-0459-1

European Commission (2010) Making our cities attractive and sustainable - how the EU contributes to improving the urban environment. Publications Office of the European Union Luxemburg $\mathrm{http}$ ://eceuropaeu/environment/europeangreencapital/wp-content/ uploads/2011/04/Making-our-cities-attractive-and-sustainablepdf Accessed 04 December 2018

Farreny R, Gabarrell X, Rieradevall J (2011) Cost-efficiency of rainwater harvesting strategies in dense Mediterranean neighbourhoods. Resour Conserv Recycl 55:686-694. https://doi.org/10.1016/j. resconrec.2011.01.008

Forchino AA, Gennotte V, Maiolo S, Brigolin D, Mélard C, Pastres R (2018) Eco-designing Aquaponics: a case study of an experimental production system in Belgium. Procedia CIRP 69:546-550. https:// doi.org/10.1016/j.procir.2017.11.064

Fuller S, Petersen S (1996) Life-cycle costing manual for the federal energy management program. NIST Handbook 135. Gaithersburg, Maryland, USA

Gilland B (2006) Population, nutrition and agriculture. Popul Environ 28(1):1-16. https://doi.org/10.1007/s11111-007-0034-9

Goldstein B, Hauschild M, Fernández J, Birkved M (2016) Urban versus conventional agriculture, taxonomy of resource profiles: a review. Agron. Sustainable Dev 36:1-9. https://doi.org/10.1007/s13593015-0348-4

Grewal SS, Grewal PS (2012) Can cities become self-reliant in food? Cities 29:1-11. https://doi.org/10.1016/j.cities.2011.06.003

Halwatura RU, Jayasinghe MTR (2009) Influence of insulated roof slabs on air conditioned spaces in tropical climatic conditions - a life cycle cost approach. Energy Build 41:678-686. https://doi.org/10. 1016/j.enbuild.2009.01.005

Hamilton AJ, Burry K, Mok HF, Barker SF, Grove JR, Williamson VG (2014) Give peas a chance? Urban agriculture in developing countries: a review. Agron sustain dev 34:45-73. https://doi.org/10.1007/ s13593-013-0155-8

Hunkeler D, Lichtenvort K, Rebitzer G (eds.) (2008) Environmental life cycle costing. SETAC, Pensacola, FL (US) in collaboration with CRC Press, Boca Raton, FL, USA

Ilg P, Scope C, Muench S, Guenther E (2017) Uncertainty in life cycle costing for long-range infrastructure. Part I: leveling the playing field to address uncertainties. Int J Life Cycle Assess 22:277-292. https://doi.org/10.1007/s11367-016-1154-1

ISO (2017) ISO 15686-5 - buildings and constructed assets - service-life planning-part 5: life-cycle costing. Nederlands NormalisatieInstitut, Delft

ISO (2008) ISO 15686-5-buildings and constructed assets - service-life planning-part 5: life-cycle costing. Nederlands NormalisatieInstitut, Delft 
ISO (2006) ISO 14040: environmental management—life cycle assessment - principles and framework. International Organization for Standardization, Geneva

Jeong IT, Lee KM (2009) Assessment of the ecodesign improvement options using the global warming and economic performance indicators. J Clean Prod 17:1206-1213. https://doi.org/10.1016/j. jclepro.2009.03.017

Jeong K, Hong T, Ban C, Koo C, Park HS (2015) Life cycle economic and environmental assessment for establishing the optimal implementation strategy of rooftop photovoltaic system in military facility. J of Clean Prod 104:315-327. https://doi.org/10.1016/j.jclepro. 2015.05.066

Kambanou ML, Lindahl M (2016) A literature review of life cycle costing in the product-service system context. Procedia CIRP 47:186191. https://doi.org/10.1016/j.procir.2016.03.054

Kim CJ, Kim J, Hong T, Koo C, Jeong K, Park HS (2015) A programlevel management system for the life cycle environmental and economic assessment of complex building projects. Environ Impact Assess Rev 54:9-21. https://doi.org/10.1016/j.eiar.2015.04.005

Kim Y, Zhang Q (2018) Economic and environmental life cycle assessments of solar water heaters applied to aquaculture in the US. Aquaculture 49:44-54. https://doi.org/10.1016/j.aquaculture.2018. 05.022

Kishk M, Al-Hajj A, Pollock R, Aouad G, Bakis N and Sun M (2003). Whole life costing in construction: a state of the art review. RICS Research Paper Series. https://openair.rgu.ac.uk/handle/10059/1085 Accessed 04 December 2018

Kloepffer W (2008) Life cycle sustainability assessment of products. Int J Life Cycle Assess 13(2):89-95. https://doi.org/10.1007/978-14020-8913-8 5

Koroneos CJ, Nanaki EA (2012) Life cycle environmental impact assessment of a solar water heater. J Clean Prod 37:154-161. https://doi. org/10.1016/j.jclepro.2012.07.001

Liaros S, Botsis K, Xydis G (2016) Technoeconomic evaluation of urban plant factories: the case of basil (Ocimum basilicum). Sci Total Environ 554:218-227. https://doi.org/10.1016/j.scitotenv.2016.02. 174

Llorach-Massana P, Peña J, Rieradevall J, Montero JI (2016) LCA \& LCCA of a PCM application to control root zone temperatures of hydroponic crops in comparison with conventional root zone heating systems. Renew energ 85:1079-1089. https://doi.org/10. 1016/j.renene.2015.07.064

Love DC, Uhl MS, Genello L (2015) Energy and water use of a smallscale raft aquaponics system in Baltimore, Maryland, United States. Aquac Eng 68:19-27. https://doi.org/10.1016/j.aquaeng.2015.07. 003

Lu HR, El Hanandeh A, Gilbert BP (2017) A comparative life cycle study of alternative materials for Australian multi-storey apartment building frame constructions: environmental and economic perspective. $\mathrm{J}$ Clean Prod 166:458-473. https://doi.org/10.1016/j.jclepro.2017.08. 065

Møller F, Slentø E, Frederiksen P (2014) Integrated well-to-wheel assessment of biofuels combining energy and emission LCA and welfare economic cost benefit analysis. Biomass Bioenergy 60:41-49

Mougeot LJ (2000). Urban agriculture: definition, presence, potentials and risks, and policy challenges. Cities feeding people series; rept $31 \mathrm{https} / / /$ idl-bnc-idrcdspacedirectorg/bitstream/handle/10625/ 26429/117785pdf?sequence=12 Accessed 04 December 2018

Nadal A, Cerón I, Cuerva E, Gabarrell X, Josa A, Pons O, SanyéMengual E (2015) Urban agriculture in the framework of sustainable urbanism. Elisava Temes de Disseny 0(31):92-103

Naves AX, Barreneche C, Fernández AI, Cabeza LF, Haddad AN, Boer D (2018) Life cycle costing as a bottom line for the life cycle sustainability assessment in the solar energy sector: a review. Sol Energy 192:238-262. https://doi.org/10.1016/j.solener.2018.04.011
Nguyen PH, Weiss S (2008) 1.4. 1 mixed-occupancy vertical urban farm systems. INCOSE International Symposium 18(1):140-155. https:// doi.org/10.1002/j.2334-5837.2008.tb00796.x

Norris GA (2001) Integrating life cycle cost analysis and LCA. Int J Life Cycle Assess 6:118-120

Opher T, Friedler E, Shapira A (2018) Comparative life cycle sustainability assessment of urban water reuse at various centralization scales. Int J Life Cycle Assess 24:1-14. https://doi.org/10.1007/s11367018-1469-1

Opitz I, Berges R, Piorr A, Krikser T (2016) Contributing to food security in urban areas: differences between urban agriculture and peri-urban agriculture in the Global North. Agr Hum Values 33(2):341-358. https://doi.org/10.1007/s10460-015-9610-2

Orsini F, Gasperi D, Marchetti L, Piovene C, Draghetti S, Ramazzotti S, Gianquinto G (2014) Exploring the production capacity of rooftop gardens (RTGs) in urban agriculture: the potential impact on food and nutrition security, biodiversity and other ecosystem services in the city of Bologna. Food Secur 6:781-792. https://doi.org/10.1007/ s12571-014-0389-6

Orsini F, Kahane R, Nono-Womdim R, Gianquinto G (2013) Urban agriculture in the developing world: a review. Agron for sustain dev 33:695-720. https://doi.org/10.1007/s13593-013-0143-z

Parece TE, Lumpkin M, Campbell JB (2016) Irrigating urban agriculture with harvested rainwater: case study in Roanoke, Virginia, USA. In: Younos T, Parece TE (eds) Sustainable Water Management in Urban Environments, The Handbook of Environmental Chemistry, vol 47. 351pp. Springer Publishers Heidelberg, Germany, pp 235264

Petit-Boix A, Llorach-Massana P, Sanjuan-Delmás D, Sierra-Pérez J, Vinyes E, Gabarrell X, Rieradevall J, Sanyé-Mengual E (2017) Application of life cycle thinking towards sustainable cities: a review. J Clean Prod 166:939-951. https://doi.org/10.1016/j.jclepro. 2017.08.030

Ragazzi M (2017) Qualitative comparative analysis. Action Res Crim Justice Restor justice approaches Intercult settings:142-192. https://doi.org/10.4324/9781315651453

Saldaña J (2003) Longitudinal qualitative research: analyzing change through time. Rowman \& Littlefield, Oxford

Sanjuan-Delmás D, Llorach-Massana P, Nadal A, Ercilla-Montserrat M, Muñoz P, Montero JI, Josa A, Gabarrell X, Rieradevall J (2018) Environmental assessment of an integrated rooftop greenhouse for food production in cities. J Clean Prod 177:326-337. https://doi.org/ 10.1016/j.jclepro.2017.12.147

Sanyé-Mengual E, Gasperi D, Michelon N, Orsini F, Ponchia G, Gianquinto G (2018) Eco-efficiency assessment and food security potential of home gardening: a case study in Padua, Italy. Sustainability 10(7):2124. https://doi.org/10.3390/su10072124

Sanyé-Mengual E, Oliver-Solà J, Montero JI, Rieradevall J (2017) The role of interdisciplinarity in evaluating the sustainability of urban rooftop agriculture. Futur Food J Food, Agric Soc 5:46-58 http:// fofjorg/indexphp/FOFJ/article/view/68 Accessed 04 December 2018

Sanyé-Mengual E, Oliver-Solà J, Montero JI, Rieradevall J (2015a) An environmental and economic life cycle assessment of rooftop greenhouse (RTG) implementation in Barcelona, Spain. Assessing new forms of urban agriculture from the greenhouse structure to the final product level. Int J Life Cycle Assess 20:350-366. https://doi.org/ 10.1007/s11367-014-0836-9

Sanyé-Mengual E, Oliver-Solà J, Montero JI and Rieradevall, J. (2015b) Using a multidisciplinary approach for assessing the sustainability of urban rooftop farming. Localizing urban food strategies. Farming cities and performing rurality. 7th International Aesop Sustainable Food Planning Conference Proceedings. Torino: Politecnico di Torino. https://www.researchgate.net/publication/298415314 Using_a_multidisciplinary_approach_for_assessing_the 
sustainability_of_urban_rooftop_farming Accessed 04 December 2018

Sanyé-Mengual E, Orsini F, Oliver-Solà J, Rieradevall J, Montero JI, Gianquinto G (2015c) Techniques and crops for efficient rooftop gardens in Bologna, Italy. Agron. Sustainable Dev 35:1477-1488. https://doi.org/10.1007/s13593-015-0331-0

Skovgaard M, Ibenholt K, Ekvall T (2007) Nordic guideline for costbenefit analysis of waste management. Nordic cooperation. Nordic Council of Ministers, Denmark

UNEP/SETAC (2011) Towards a life cycle sustainability assessment. Making informed choices on products. Life Cycle Initiative https:// www.lifecycleinitiative.org/wp-content/uploads/2012/12/2011\% 20-\%20Towards\%20LCSA.pdf Accessed 04 December 2018

Scope C, Ilg P, Muench S, Guenther E (2016) Uncertainty in life cycle costing for long-range infrastructure. Part II: guidance and suitability of applied methods to address uncertainty. Int J Life Cycle Assess 21:1170-1184. https://doi.org/10.1007/s11367-016-1086-9

Specht K, Siebert R, Hartmann I, Freisinger UB, Sawicka M, Werner A, Dierich A (2014) Urban agriculture of the future: an overview of sustainability aspects of food production in and on buildings. Agr hum values 31:33-51. https://doi.org/10.1007/s10460-013-9448-4

Swarr TE, Hunkeler D, Klöpffer W, Pesonen HL, Ciroth A, Brent AC, \& Pagan R (2011). Environmental life-cycle costing: a code of practice. Int J Life Cycle Assess 16: 389. https://doi.org/10.1007/ s11367-011-0287-5, 391

Thomaier S, Specht K, Henckel D, Dierich A, Siebert R, Freisinger UB, Sawicka M (2015). Farming in and on urban buildings: present practice and specific novelties of zero-acreage farming (ZFarming). Renew Agric Food Syst 30: 43-54 https:// wwwcambridgeorg/core/journals/renewable-agriculture-and-foodsystems/article/farming-in-and-on-urban-buildings-presentpractice-and-specific-novelties-of-zeroacreage-farming-zfarming/ B1B85E6F51C51DBF134879F8C7565461 Accessed 04 December 2018

UN DESA (2018) United Nations Department of Economic and Social Affairs, Population Division. World Population Prospects: The 2018 Revision, Highlights. New York. https://population.un.org/wup/ Publications/Files/WUP2018-KeyFacts.pdf Accessed 18 July 2019
UN DESA (2004) United Nations Department of Economic and Social Affairs, Population Division. World population to 2300. New York. https://www.un.org/en/development/desa/population/publications/ pdf/trends/WorldPop2300final.pdf. Accessed 18 July 2019

Vargas-Parra MV, Rovira MR, Gabarrell X, Villalba G (2014) Costeffective rainwater harvesting system in the Metropolitan Area of Barcelona. J Water Supply Res Technol - AQUA 63:586-595. https://doi.org/10.2166/aqua.2014.108

Wong NH, Tay SF, Wong R, Ong CL and Sia A (2003). Life cycle cost analysis of rooftop gardens in Singapore. Build Environ 38: 499450. https://doi.org/10.1016/S0360-1323(02)00131-2

Woodward DG (1997) Life cycle costing - theory, information acquisition and application. Benis K, Ferrão P (2018) Commercial farming within the urban built environment - taking stock of an evolving field in northern countries. Glob Food Sec 17:30-37. https://doi. org/10.1016/j.gfs.2018.03.005

Wu S, Longhurst P (2011) Optimising age-replacement and extended non-renewing warranty policies in lifecycle costing. Int J Prod Econ 130:262-267. https://doi.org/10.1016/j.ijpe.2011.01.007

Zhao PP, Meng FR (2014). Agricultural water conservation cost control mechanism of the pre-coastal city based on design innovation. Int Conf Mach Tool Technol Mechatronics Eng ICMTTME 2014644 650:5962-5965. https://doi.org/10.4028/www.scientific.net/AMM. 644-650.5962

Zidar K, Belliveau-Nance M, Cucchi A, Denk D, Kricun A, O'Rourke S, Rahman S, Rangarajan S, Rothstein E, Rothstein E, Shih J, Montalto F (2017) A framework for multifunctional green infrastructure investment in Camden, NJ. Urban Plan 2:56. https://doi.org/10.17645/ up.v2i3.1038

Zinia NJ, McShane P (2018) Ecosystem services management: an evaluation of green adaptations for urban development in Dhaka, Bangladesh. Landsc Urban Plan 173:23-32. https://doi.org/10. 1016/j.landurbplan.2018.01.008

Publisher's note Springer Nature remains neutral with regard to jurisdictional claims in published maps and institutional affiliations. 